\title{
Historical Review and Update of Surgical Treatment for Corneal Endothelial Diseases
}

José L. Güell • Mostafa A. El Husseiny · Felicidad Manero •

Oscar Gris $\cdot$ Dani Elies

To view enhanced content go to www.ophthalmology-open.com

Received: May 13, 2014 / Published online: February 18, 2014

(C) The Author(s) 2014. This article is published with open access at Springerlink.com

\section{ABSTRACT}

The cornea remains in a state of deturgescence, maintained by endothelial cell $\mathrm{Na}+/ \mathrm{K}+$ ATPase and by tight junctions between endothelial cells that limit entrance of fluid into the stroma. Fuchs' endothelial corneal dystrophy (FECD) was initially described by Fuchs in 1910 as a combination of epithelial and stromal edema in older patients. It manifests as bilateral, albeit asymmetric, central corneal guttae, corneal edema, and reduced vision. When edema is severe, the corneal epithelium can detach from its basement membrane, creating painful bullae on the anterior surface of the cornea. The course of this dystrophy can be further accelerated after intraocular surgery, specifically cataract

Electronic supplementary material The online version of this article (doi:10.1007/s40123-014-0022-y) contains supplementary material, which is available to authorized users.

J. L. Güell $(\bowtie) \cdot$ F. Manero · O. Gris · D. Elies Cornea and Refractive Surgery Unit, Autonoma University of Barcelona, C/Josep Ma Lladó, 08035 Barcelona, Spain e-mail: guell@imo.es

M. A. El Husseiny

Cornea and Refractive Surgery Department, Research Institute of Ophthalmology (RIO), Giza, Egypt extraction. Pseudophakic bullous keratopathy (PBK) is endothelial cell loss caused by surgery in the anterior chamber. If the corneal endothelium is damaged during surgery, the same spectrum of symptoms as found in FECD can develop. In the nineteenth century, penetrating keratoplasty was the only surgical procedure available for isolated endothelial disease. In the 1960s, Dr. José Barraquer described a method of endothelial keratoplasty using an anterior approach via laser-assisted in situ keratomileusis (LASIK) flap. In 1999, Melles and colleague described their technique of posterior lamellar keratoplasty. Later, Melles et al. started to change host dissection using simple "descemetorhexis" in a procedure known as Descemet's stripping endothelial keratoplasty. Following the widespread adoption of Descemet's stripping automated endothelial keratoplasty, the Melles group revisited selective Descemet's membrane transplantation and reported the results of a new procedure, Descemet's membrane endothelial keratoplasty (DMEK). Recently, some eye banks have experimented with the preparation of DMEK/Descemet's membrane automated endothelial keratoplasty donor 
tissue that may help the surgeon avoid the risk of tissue loss during the stromal separation step. Recently, the authors described a new bimanual technique for insertion and positioning of endothelium-Descemet membrane grafts in DMEK.

Keywords: Endothelial; Disease; Endothelial transplant; Fuch's dystrophy; Ocular surgery; Ophthalmology; Posterior lamellar keratoplasty; Pseudophakic bullous edema

\section{INTRODUCTION}

The adult human cornea averages $540 \mu \mathrm{m}$ in thickness [1], with the following layers from anterior to posterior: epithelium, Bowman's membrane, stroma, Descemet's membrane (DM), and endothelium. The cornea remains in a state of deturgescence, maintained by endothelial cell $\mathrm{Na}+/ \mathrm{K}+$ ATPase and by tight junctions between endothelial cells that limit entrance of fluid into the stroma. By maintaining an optimum level of corneal hydration, endothelial cells preserve the ordered arrangement of collagen, which is crucial for corneal transparency [2]. When endothelial cell density is low, the loss of tight junctions between cells allows more fluid to enter the stroma. The endothelial cells that remain may have a higher concentration of $\mathrm{Na}+/ \mathrm{K}+$ ATPase in an effort to compensate for the loss [1].

The average human cornea has an endothelial cell density of 5,000-6,000 cells/ $\mathrm{mm}^{2}$ at birth, decreasing to 2,500-3,000 cells/ $\mathrm{mm}^{2}$ by adulthood. There is an average cell loss of $0.6 \%$ per year [1]. Corneal edema appears at $700-400$ cells $/ \mathrm{mm}^{2}[1,3]$. Adult human corneal endothelial cells are arrested in the $G$ phase of the cell cycle and do not undergo mitosis [4].
Therefore, lost cells cannot be replaced physiologically.

This review follows the development of surgical treatment of endothelial diseases, from penetrating keratoplasty to different approaches of selective endothelial keratoplasty.

\section{METHODS}

For this review, the authors searched PubMed using the keywords "Endothelial disease; Endothelial transplant; Fuch's dystrophy; Ocular surgery; Posterior lamellar keratoplasty; Pseudophakic bullous edema". They also searched ophthalmology books about cornea and papers published in the last decades discussing the different steps of evolution of corneal surgeries and management of endothelial diseases. The article is divided to subsequent headlines putting into consideration the chronological evolution (abstract, introduction, methods, indications for keratoplasty, keratoplasty in the nineteenth century, keratoplasty in the early twentieth century, use of the human cornea, fixation techniques, establishment of eye banks, development of endothelial keratoplasty, conclusion and references). The authors used the statistics of the eye bank association of America. The abstract, the full article and references were obtained and references checked for additional material where appropriate.

\section{INDICATIONS FOR KERATOPLASTY}

Fuchs' endothelial corneal dystrophy (FECD) was initially described by Fuchs [5] in 1910 as a combination of epithelial and stromal edema in older patients. It manifests itself as bilateral, albeit asymmetric, central corneal guttae, corneal edema, and reduced vision $[6,7]$. The 

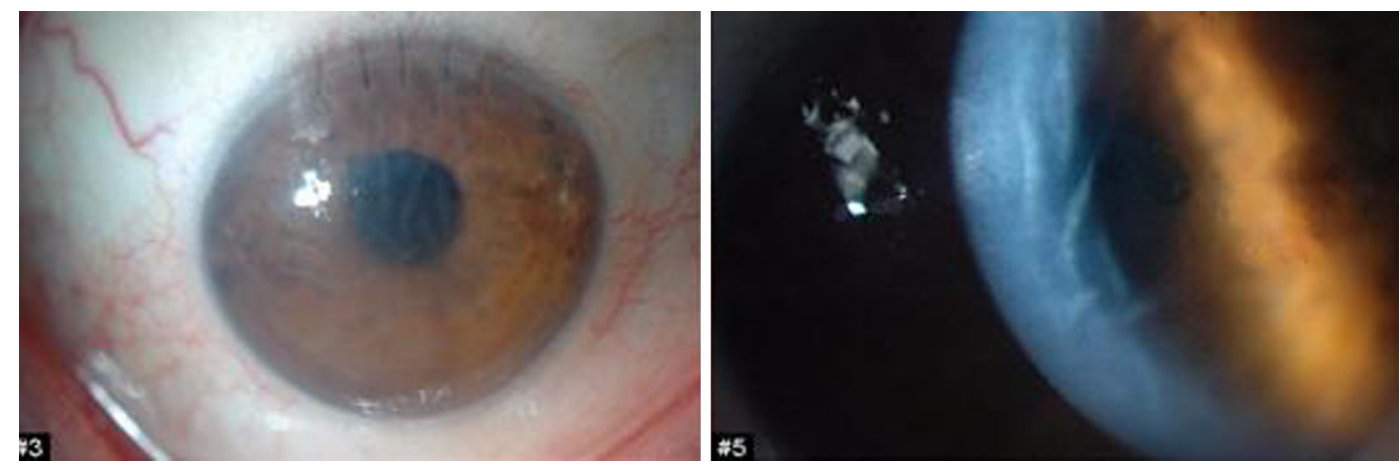

Fig. 1 Corneal edema in a pseudophakic eye with Fuchs' endothelial corneal dystrophy

DM thickens and develops excrescences known histopathologically as guttae. Stromal edema develops and corneal thickness may increase to over $1,000 \mu \mathrm{m}$. When the edema is severe, the corneal epithelium can detach from its basement membrane, creating painful bullae on the anterior surface of the cornea $[2,8]$. FECD is the most common endothelial dystrophy and is usually seen beyond the fifth decade of life, although not all cases are in the elderly; Biswas et al. [9] reported several families with early onset of this dystrophy in the third and fourth decades of life. FECD is, despite its dominant inheritance form, more common and progressive in women [10]. It may also present in a sporadic form and is thought to be a primary disorder of the endothelium. The total number of endothelial cells is low and existing cells may not function properly. The course of this dystrophy can be further accelerated after intraocular surgery, specifically cataract extraction. A cell count of less than 1,000 cells $/ \mathrm{mm}^{2}$ or corneal thickness greater than $640 \mu \mathrm{m}$ are considered major risk factors for corneal decompensation after cataract surgery [11-13].

Pseudophakic bullous keratopathy (PBK) is a term used to describe endothelial cell loss caused by surgery in the anterior chamber. If the corneal endothelium is damaged during surgery (as often occurs during cataract extraction) [3], the same spectrum of symptoms as found in FECD can develop, although the histological phenotype of both diseases is different and there is no guttata in PBK (Fig. 1).

Toxic anterior segment syndrome (TASS) is a rare complication of intraocular surgery that has only recently been recognized [14]. It is an acute sterile inflammation in the anterior segment caused by noxious agents such as medications, residual viscoelastic agents, and preservatives, or by an altered osmolarity or $\mathrm{pH}$ of the irrigating solution [15-17]. Permanent corneal endothelial damage can occur in severe cases of TASS.

\section{KERATOPLASTY IN THE NINETEENTH CENTURY}

In the nineteenth century, penetrating keratoplasty (PK) was the only surgical procedure used for isolated endothelial disease whether it was FECD or PBK; however, this procedure proved unsuccessful because of a total lack of knowledge about many basic concepts that could prevent failure, such as sepsis, immunology and tissue biology, anatomy and physiology of the cornea, and anesthesia. 
The concept of removing a cloudy cornea was discussed by Charles Darwin's grandfather, Erasmus Darwin, in 1796. He felt that after an ulcer of the cornea, the scar could be cut out and have it heal with a transparent scar [18]. In 1824, Franz Reisinger [19] coined the term 'keratoplasty' and he is credited with this term, although controversy surrounds this attribution. During this period, it was believed that the human cornea could be replaced with an animal cornea from another species. Wilhelmus Thome, in 1834, was the first to use the term 'corneal transplantation', although he did not undertake such a procedure [18]. Records suggest that the first successful transplant was performed by James Bigger, who, when captured by Saharan Bedouins, was able to achieve his freedom by transplanting the opaque cornea of the pet gazelle belonging to the head sheik using another gazelle's cornea [20]. Kissam [21], in 1844, discussed guidelines for keratoplasty, which although written many years ago are actually accurate for current keratoplasty techniques. Kissam suggested that the donor and recipient should be of the same size, there should be rapid and atraumatic transfer of donor tissue with minimal tissue damage, and that there should be careful corneal fixation and protection of the intraocular contents.

Henry Power [22] recommended corneal transplantation within the same species. In 1877, Von Hippel started publishing his studies using circular mechanical trephines to remove the donor and recipient corneas. This same technique is used for keratoplasty procedures today. Von Hippel did, however, set back keratoplasty for a time, as he recommended heteroplastic over homoplastic tissue [18]. Other factors leading to successful corneal transplantation included the development of general anesthesia. This was first used in 1846, in the Etherdome at Massachusetts General Hospital, and was followed by the introduction of chloroform in 1847. In 1867, Lister first brought attention to the importance of an aseptic setting for successful surgery. Topical cocaine was discovered by Kohler in 1884 [18].

\section{KERATOPLASTY IN THE EARLY TWENTIETH CENTURY}

The first visually successful human corneal transplant was performed on December 7, 1905, in Olmutz, a small Moravian city near Prague in Slovakia. It was performed by Dr. Eduard Zirm on Alois Golgar [23], who had bilateral blindness caused by lime injury. Both corneas were severely scarred centrally, leaving some peripheral clarity. His visual acuity was hand motions in both eyes. Karl Braur, an 11-year-old boy, was the donor. He experienced loss of vision following an intraocular metallic foreign body injury in July 1905. Zirm enucleated the blind eye and used the donor's clear cornea to form two 5.0-mm donor corneas. He removed the corneas with a 5.0-mm von Hippel trephine.

Zirm kept the transplants in place with a bridge of conjunctiva, sutured over the corneas. The patient's left corneal transplant was trephined from a more central part of Braur's donated cornea. The right corneal transplant failed and had to be removed, but the left transplant cleared and Golgar was sent home 15 weeks after the operation. A year afterward, an ophthalmologist checked Golgar's visual acuity and found it to be 6/36 with a stenopeic disc. Zirm died in March 1944 without recording any other corneal transplants in his 45 publications. 
The majority of research into keratoplasty was conducted in Europe. Magitot [24] successfully used preserved corneas as early as 1911, and Elschnig [25] performed 170 corneal transplants in his Prague clinic with 22\% success rate, and without the use of topical antibiotics or steroids. During this time, most of the corneal transplants were small, approximately $4.0 \mathrm{~mm}$, and were kept in place either by conjunctival flaps, with lid closure, or by fixation sutures placed across the cornea, as performed by Zirm.

\section{USE OF THE HUMAN CORNEA}

In 1921, Harry Gradle [26] highlighted the uniformly unsuccessful results for keratoplasty. Up until this time, only single case reports had been published and in only one instance were two cases published [26]. None of the patients who underwent keratoplasty had good vision and Gradle concluded that transplantation from another species was a biologic impossibility (whether or not transplants could be done successfully within the same species was not completely agreed upon). He did not refer to Elschnig's work in Prague, where corneal transplants in humans had been performed for at least 10 years with some modicum of success.

In England in the 1930s, Sir Tudor Thomas [27] experimented with corneal transplantation using rabbits' eyes. He felt that it was premature to operate on humans when the results were so unsuccessful.

By the mid-1930s, when transplantation had become more successful, there were insufficient diseased eyes with clear corneas requiring enucleation to satisfy the needs of the corneal transplant surgeons, who had many bilaterally blind patients on their lists. Elschnig supported the use of cadaver corneas, but it was Vladimir Filatov [28] who was primarily responsible for popularizing the use of cadaver corneas for corneal transplant purposes. Filatov [28], in a review of corneal transplantation, mentioned the use of cadaver corneas stored in an ice chest at $4{ }^{\circ} \mathrm{C}$. The eyes were enucleated 'within $2-3 \mathrm{~h}$ before the body was taken to the morgue, or while in the morgue, certainly within just a few hours of death [28]. The corneas were used within 20-56 h after death [28]. These early techniques for cadaver enucleation are still used today in many countries. Other corneal surgeons preceded Filatov with individual case reports of using cadaver corneas for corneal transplantation, but it was Filatov who was credited with popularizing this approach.

\section{FIXATION TECHNIQUES}

Fixation technique is important in the outcome of corneal transplantation. Many methods have been used to ensure the proper alignment of the donor cornea, beginning with just conjunctival flaps and crossed sutures over the cornea. In the beginning only small grafts, less than $4.0 \mathrm{~mm}$, were used. With these small grafts, overlay sutures were satisfactory for stabilization when the suture material was equivalent to $4-0$ or $5-0$ silk [18].

Numerous techniques have been described in the literature for corneal fixation [29]. Most of these fixation techniques preceded edge-toedge appositional sutures. The sutures were anchored in the sclera beyond the cornea and were removed soon after corneal transplantation because of loosening and vascularization. Ramon Castroviejo's unusual technique of square corneal transplants created with a parallel razorblade was utilized until the 1960s, mostly for keratoconus. He felt that a 
square graft, with one point directed toward 6 o'clock, provided better stability in keratoconus.

Castroviejo's [30, 31] investigations of keratoplasty, his design of unique instruments, and his exquisite skill almost single-handedly improved techniques and popularized corneal transplants in the 1940s and 1950s. Aside from Ramon Castroviejo, few ophthalmologists in the USA were performing corneal transplantation, either experimentally or on humans, before World War 2. A corneal transplant symposium, sponsored by the American Academy of Ophthalmology, was held for the first time at Palmer House in Chicago in October 1947. A panel of physicians, including R. Townley Paton, John M. McLean, Ramon Castroviejo, Kornblueth and Edward Maumenee, presented at this symposium. Paton [32] spoke about patient selection, while McLean [33] discussed keratoplasty technique, quoting liberally from Castroviejo's work, which dated back to 1932. Castroviejo reviewed complications and the overlay suture for fixation [34]. Complications of keratoplasty included significant anterior synechiae, iris prolapse, infections, glaucoma, vascularization, inflammation, edema, and deformity due to the protruding edges of the transplant during the postoperative period.

Also at the symposium, Maumenee and Kornbleuth [35] discussed the physiopathology of corneal transplants. During 1947 it was unclear whether the new graft was merely a framework for ingrowth of recipient cells, or whether the donor stromal cells and endothelium persisted. The importance of the corneal endothelium in maintaining corneal hydration was still not appreciated. Stocker's [36] work in 1952, brought attention to the donor endothelium in keratoplasty. Davson in England, Harris and Nordquist, Mishima and
Hedbys, and Dohlman, as well as Morris, all in the USA, were to make major contributions towards the understanding of the importance of the corneal endothelium. Specular microscopy was not performed until the mid-1960s, and the longevity of the endothelium in keratoplasty was subjected to more research, particularly by Bourne [37]. Paufique, Sourdille, and Offret in Paris, Billingham and Boswell in England, and Pollack in New York, as well as Khodadoust and Silverstein in Baltimore, were working on graft rejection. The endothelial rejection line was named after Ali Khodadoust [38], an ophthalmologist still working in Connecticut today. In the results section of this first American Academy of Ophthalmology Symposium on corneal transplantation, Owens [39] discussed a study of 417 grafts of which $36.5 \%$ remained clear. The best results were with keratoconus, of which $66 \%$ were clear and hereditary dystrophies (59\% clear). There were no clear grafts obtained in patients who had FECD. Max Fine, in San Francisco, was the first corneal surgeon to perform a transplant west of the Mississippi and to advocate keratoplasty for FECD and aphakic bullous keratopathy [40].

The surgical techniques for keratoplasty were slowly changing due to better instrumentation and suture material. By 1950, José Barraquer [41], a pioneer in keratoplasty in Barcelona, Spain, was using donor tissue up to $6.5 \mathrm{~mm}$ in diameter with direct suturing using fine silk sutures and very sharp Grieshaber needles (Grieshaber, Schaffhausen, Switzerland). In the late 1950s and early 1960s, Mackensen and Harms at the University of Tubingen, in West Germany, initiated the use of nylon sutures. They were among the first to change from silk to nylon for direct appositional suturing. Richard Troutman [42], in 1963, introduced these sutures to the USA, along with the microscope, for keratoplasty. In 1968, 10-0 
nylon for keratoplasty was introduced commercially by Ethicon (Johnson \& Johnson, New Brunswick, NJ, USA).

\section{ESTABLISHMENT OF EYE BANKS}

As corneal transplantation became more successful, the need for corneas from cadavers increased. Eye banking began in the 1940s, when Paton established the first eye bank in the USA-the Eye Bank for Sight Restoration, founded in New York in 1944. In 1961, the Eye Bank Association of America was established. Statistics for corneal transplants compiled by the Eye Bank Association of American their first year showed that approximately 2,000 transplants were performed in 1961. In 2005, approximately 36,000 transplants were undertaken in the USA from tissue obtained from the Eye Bank Association of America collaborating eye banks, while another 9,000 corneas were sent overseas for transplantation. In 2012, corneal tissue supplied by US banks for keratoplasty of all types was 68,681 , a $1.6 \%$ increase from 67,590 in 2011. A total of 19,546 corneas were exported internationally in 2012 compared with 18,307 in 2011, a 6.8\% increase [43].

In the era of using cadaver corneas from whole eyes, it was necessary to operate within $48 \mathrm{~h}$ of death to preserve the donor endothelium. This was inconvenient for the patient, the surgeon, and the operating room staff, as well as only marginally healthy for the corneal endothelium, which was bathed in aging aqueous fluid. The concept of corneal storage in artificial media was introduced by McCarey and Kaufman [44] in the early 1970s. They employed tissue culture media and various enhancements to maintain the endothelium, with antibiotics added later to prevent infection. Almost all corneal transplants in the USA are performed today using corneas that have been stored at $4{ }^{\circ} \mathrm{C}$ in corneal storage media. In the UK and Europe organ culture is the storage method of choice.

Corneal storage media have improved continually so that corneas may now be stored for at least a week, maintaining excellent corneal endothelial physiology. The endothelium continues to be an important subject of research, as even 15 years after keratoplasty, endothelial failure is a major cause of graft failure [45].

In the 100-year review of the cornea, by Laibson and Rapuano [46], published in 1996 for the 100th anniversary of the American Academy of Ophthalmology, corneal transplantation was considered well accepted with a success rate of $90 \%$ for keratoconus, FECD, and PBK, the three most important diseases requiring keratoplasty.

There are of course several problems with penetrating corneal transplants. The length of time for best-corrected vision (BCVA) after PK can be 18 months or longer because of selective suture removal. With silk sutures knotted on the surface, healing was usually complete within 21 days, after which the sutures were removed. With nylon sutures, which quickly bury beneath the surface, the healing period for a corneal transplant is much longer. It is now routine for surgeons to leave interrupted and running sutures in place for at least a year, and if vision is good, with or without correction and with little astigmatism, the sutures are left in even longer. One of the problems with the nylon suture is that it can break and breakage is relatively unpredictable. Also, astigmatism after corneal transplantation has been one of the main problems leading to unsatisfactory vision, even though the graft may be clear [18]. 


\section{DEVELOPMENT OF ENDOTHELIAL KERATOPLASTY}

The history of endothelial keratoplasty (EK) began in 1956 when Tillett [47] published the first description of posterior lamellar keratoplasty (PLK). Although this used a fullthickness large-incision, it was the first attempt to use the inner layer of the cornea for treating corneal diseases caused by endothelium. In the 1960s, Dr. José Barraquer [48] described a method of EK using an anterior approach via laser-assisted in situ keratomileusis LASIK flap. After cutting a partial thickness flap with a microkeratome, the posterior cornea consisting of stroma, DM, and endothelium was trephined and replaced with a donor graft that was sutured in place. The flap was then replaced and also sutured.

In 1999, Melles and colleagues [49, 50] directed in the field to an intrastromal approach, describing a large pocket dissection through a sclero-corneal pocket incision that held a donor without sutures. Their technique of PLK avoided some of the pitfalls of fullthickness surgery, but involved a difficult dissection of both donor and host. One of the major advantages, however, was the use of air instead of sutures to initially secure the donor tissue. Sutures have been associated with a host of complications not limited to breakage, infections, and, of course, the risks associated with full-thickness grafts such as acute glaucoma and rejection. The point sources of tension from sutures and the alignment of fullthickness stromal cuts are major contributors to the unpredictable variations in both regular and irregular astigmatism [51].

Later Melles et al. [52] started to change host dissection using simple "descemetorhexis" in a procedure known as "Descemet's stripping endothelial keratoplasty" (DSEK). Their internal approach of removing DM from the host left an ultrasmooth posterior surface on which the dissected donor stromal disc could be fixed. Gorovoy [53] used a microkeratome to harvest the donor tissue to perform Descemet's stripping automated endothelial keratoplasty (DSAEK). This was a successful surgical procedure that yielded good results. However, all too often, on pristine slit-lamp examination, postoperative vision was limited from 20/30 to 20/50 for no apparent reason [54]. The interface was usually blamed as the cause of decreased vision. However, LASIK patients who also had an interface, routinely achieved 20/20 or better vision. Clearly, the tissue could be removed more precisely in LASIK than it could be added in DSAEK.

DSAEK has been shown to achieve faster visual recovery, lower postoperative astigmatism, and a lower incidence of graft failure than PK [55]. In a comparison of PK with DSAEK, more than 1 year after transplantation, DSAEK had a statistically insignificant higher rate of repeat grafting at 15 months [56]. Regardless of this, DSAEK is highly successful and has been widely adopted. In a cohort study of 12 patients who underwent DSAEK surgery in one eye and PK in the other, all patients reported higher satisfaction with the DSAEK procedure and achieved better uncorrected visual acuity (UCVA) and best-corrected visual acuity (BCVA) [57].

Following the widespread adoption of DSAEK surgery, the Melles group [58] revisited selective DM transplantation and reported the results of a new procedure, DM endothelial keratoplasty (DMEK). In DMEK, the donor DM was stripped from a corneoscleral rim and injected into the host anterior segment, which had been stripped of its own DM, via a 3-mm clear corneal incision. The membrane was unrolled using pneumatic and fluidic 
manipulations and opposed to the recipient posterior stroma using the air bubble technique. The initial results were encouraging; of 10 eyes transplanted, four had BCVA of better than 20/40 1 week after surgery and 6 achieved greater than 20/40 BCVA at week 6 postoperatively. Moreover, this simplified technique negated the need for an automated microkeratome to smooth a stromal graft, allowing this technique to be accessible to a greater number of surgeons. The Melles group [59] subsequently presented their first 50 cases of DMEK; of those eyes where the Descemet's graft adhered ( $n=40,80 \%), 75 \%$ achieved best spectacle-correct visual acuity (BSCVA) of 20/25 or better within 3 months.

In December 2009, 2 months after the Melles paper, Price et al. reported their prospective study of 60 DMEK procedures in 56 eyes in the United States. Their results were similar to the Melles study; the Price group [60] reported 63\% of eyes with a BCVA of $20 / 25$ or better and $94 \%$ with vision of $20 / 40$ or better at 3 months. This was significantly better than the results achieved with DSAEK surgery.

Initial endothelial cell counts following DMEK are comparable with PK and DSAEK. The Melles group reported an average endothelial cell density of 1,850 cells $/ \mathrm{mm}^{2}$ at 6 months after surgery and 1,680 cells $/ \mathrm{mm}^{2}$ at 12 months [61]. The Price group [60] reported a mean endothelial cell loss of $30 \%$ at 3 months. These results are similar to values reported after DSEK, DSAEK, and PK [55, 62-65]. Each iteration of EK has brought corneal surgeons one step closer to pure endothelial cell transplantation and even more innovative treatments for diseases of the endothelium. The Melles group [66], for example, recently reported spontaneous corneal clearing after DMEK in a patient with a previous permanently dislocated graft. Therefore, could corneal clarity be achieved in the absence of a permanent graft?

Submerged cornea using backgrounds away (SCUBA) technique, which is a method for preparing DMEK donor tissue, has previously been described [67]. Separating DM while submerged in fluid allowed for easy handling and removed the effect of surface tension on tear promotion. The technique was consistently reliable, used simple instruments that were readily available, and could be taught to eye bank technicians.

The key technique for successful implantation is "the Dead Sea Scrolls" method [68]. This term highlighted the natural scrolling tendency of a stroma-free DM, and the correct orientation of the endothelial side before the donor scroll was fixed in position with air. The technique also included no-touch manipulation using microjets of fluid, externally induced eddy currents, surface tension, and air bubbles to unroll, position, and secure the donor in the confines of the anterior chamber. Visualization of the donor was enhanced with trypan blue staining. It was found that proper air management could prevent the dislocations that had initially been described. In addition, the difference in curvature between the donor and the host, that often leads to peripheral detachments, could be easily treated by rebubbling with air $[68,69]$.

Studeny et al. [70] realized that leaving a rim of stroma in the periphery of the donor cornea remarkably improved handling inside the eye, whilst still providing the visual benefits of DMEK. This was referred to as "DMEK with a stromal rim". Other variations were proposed by Price with DMAEK (DM automated endothelial keratoplasty), and by Busin with "sickle" DMEK [71-73]. Tissue was prepared using a microkeratome and a stromal air injection (big bubble) to harvest donor tissue and was 
successful in skilled hands [74, 75]. However, in exchange for the ease of intraoperative placement, this technique required an expensive microkeratome, offered its own challenges, and DMAEK or sickle DMEK tissue preparation was not consistently successful.

Recently, some eye banks have experimented with the preparation of DMEK/DMAEK donor tissue that may help surgeons avoid the risk of tissue loss during the stromal separation step [43]. Today's DMEK surgeons have that option and may obtain eye bank-prepared tissue or prepare the tissue themselves.

In 2013 Ether et al. describe a standardized 'no-touch' harvesting technique of anterior membrane and DM grafts for use in deep anterior lamellar keratoplasty (DALK) and DMEK, which provides undamaged anterior and posterior corneal grafts [76].

Regarding the presence of stromal tissue on the DM of the donor tissue, Yoeruek et al. [74] examined the dissection plane achieved when pneumatic dissection is used to create the donor graft for EK; they found no stroma attached to the DM on either light or electron microscopy, implying a complete separation of stroma and DM. On the contrary, another recent, smaller study documented residual stroma on the DM by light microscopy after pneumatic dissection [77]. These differences were attributed to differences in methodology between both studies [78]. Recently, the present authors described a new bimanual technique for insertion and positioning of endothelium-DM (EDM) grafts in DMEK [79].

In a prospective, non-comparative, consecutive, interventional case series, which included 15 pseudophakic eyes of 15 patients treated with DMEK (Fig. 2), a bimanual infusion technique was used to introduce and position donor's EDM [79]. Partial tamponade was achieved with $20 \%$ sulfur fluoride (SF6). Intraocular manipulation time of EDM grafts, rebubbling rate, and endothelial cell density were evaluated. Six months postoperatively, mean UCVA and BSCVA had improved from $20 / 100$ to $20 / 50$, and from 20/80 to 20/25, respectively, $(P<0.001)$. Six $(40 \%)$ eyes had $\geq 20 / 20$ BSCVA, and 13 (86\%) eyes had $\geq 20 / 30$ BSCVA. Mean donor cell density decreased from $2,690 \pm 302$ cells $/ \mathrm{mm}^{2}$ to $1,998 \pm 621$ cells $/ \mathrm{mm}^{2}$, representing a mean cell loss of $26 \pm 20 \%$ after 6 months. EDM was stripped successfully in all cases. Mean intraocular manipulation time of donor's EDM (interval between main incision closure and final EDM positioning) was $4.10 \pm 0.5 \mathrm{~min}$. Intracameral air reinjection was needed in one case (6.6\%) with a partial, peripheral graft detachment. No episodes of immunological graft rejection were documented [79].

A recent study showed for the first time that leucine-rich repeat-containing G-protein coupled receptor 5 (LGR5) is uniquely expressed in the peripheral region of human corneal endothelial cells and that LGR5 ${ }^{(+)}$cells have some stem/progenitor cell characteristics [80]. Furthermore, in human corneal endothelium, LGR5 is the target molecule and negative feedback regulator of the Hedgehog (HH) signaling pathway. Interestingly, the findings of this study show that persistent LGR5 expression maintained endothelial cell phenotypes and inhibited mesenchymal transformation (MT) through the Wnt pathway. Moreover, R-spondin-1, an LGR5 ligand, dramatically accelerated corneal endothelial cell proliferation and also inhibited MT through the Wnt pathway. These findings provide new insights into the underlying homeostatic regulation of human corneal endothelial stem/progenitor cells by LGR5 via the HH and Wnt pathways [79]. 
(a)
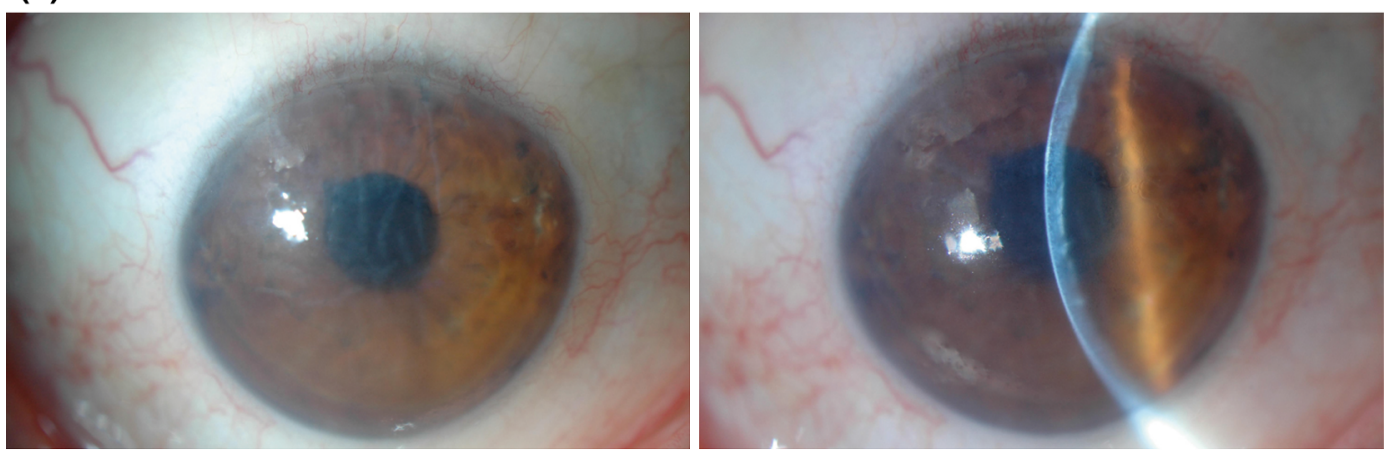

(b)
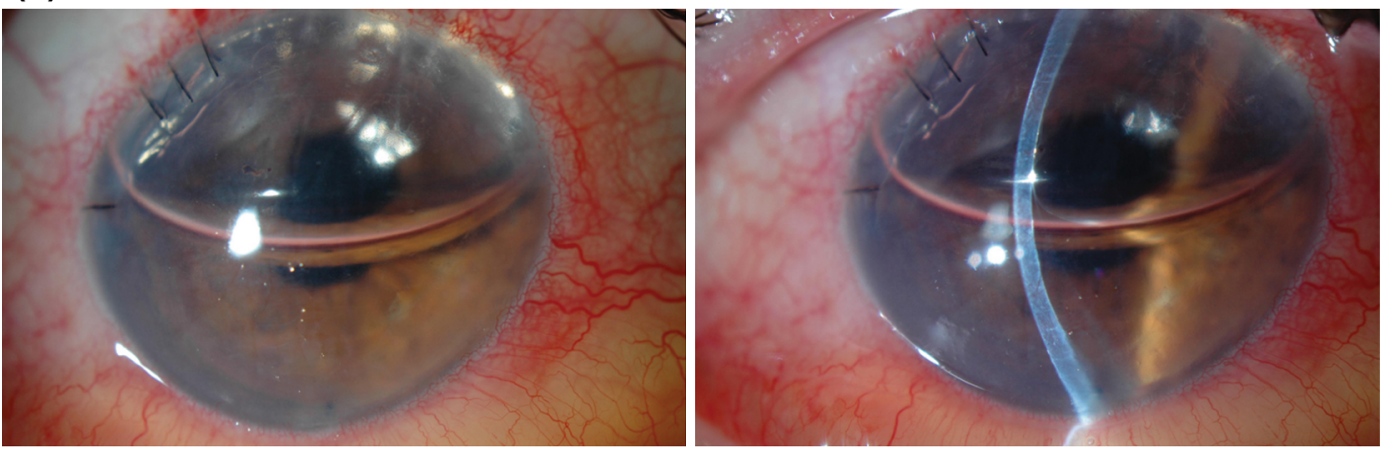

(c)
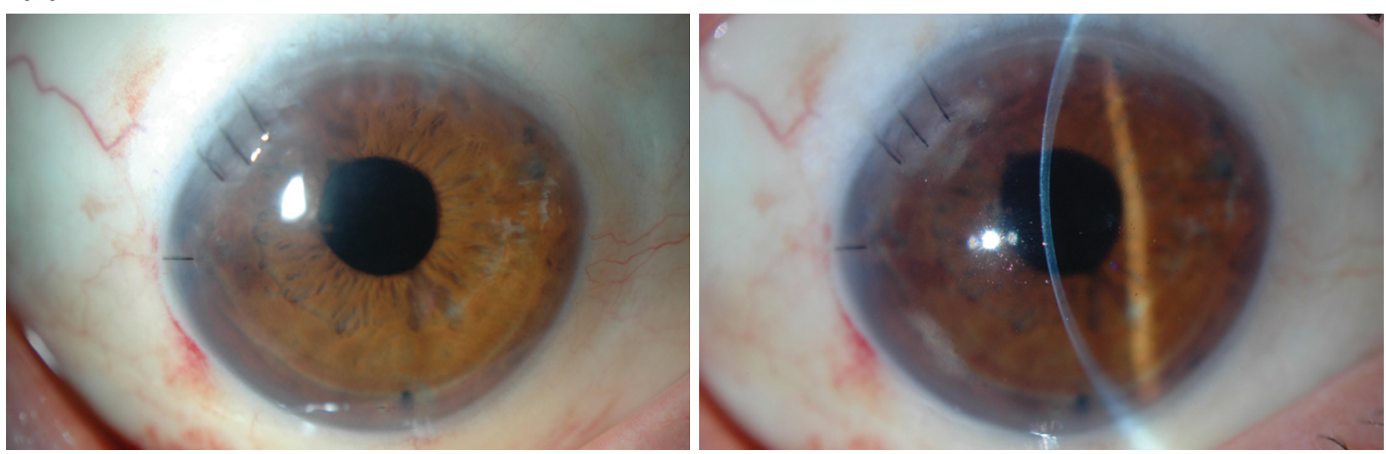

Fig. 2 Pseudophakic eye with Fuchs' endothelial corneal dystrophy treated by Descemet membrane endothelial keratoplasty: a Preop: BSCVA: 0,05. b 24 h. postop. VA: 0,16. c 20 days postop. BSCVA: 0,9

\section{CONCLUSION}

Until today, corneal endothelial disease has been treated by tissue substitution. Endothelial transplantation techniques have significantly progressed during the last 10 years being DSAEK and finally DMEK their best examples of selectivity. On the other hand, research in drugs directed to improve EC health is also increasing, in clinical practice during the next few years. Hopefully, gene therapy will pay attention to corneal endothelial diseases in the near future. We think this will be a great achievement in the field of management of corneal endothelial diseases. 


\section{ACKNOWLEDGMENTS}

No funding or sponsorship was received for this study or publication of this article.

All named authors meet the ICMJE criteria for authorship for this manuscript, take responsibility for the integrity of the work as a whole, and have given final approval for the version to be published.

Conflict of interest. Mostafa A. El Husseiny, Jose L. Güell, Felicidad Manero, Oscar Gris and Dani Elies declare no conflicts of interest.

Compliance with ethics guidelines. This article does not contain any new studies with human or animal subjects performed by any of the authors.

Open Access. This article is distributed under the terms of the Creative Commons Attribution Noncommercial License which permits any noncommercial use, distribution, and reproduction in any medium, provided the original author(s) and the source are credited.

\section{REFERENCES}

1. Edelhauser HF. The balance between corneal transparency and edema: the Proctor Lecture. Invest Ophthalmol Vis Sci. 2006;47:1755-67.

2. Kumar V, Fausto N, Abbas A. Robbins and Cotran pathologic basis of disease. 7th ed. Elsevier Saunders; 2004.

3. Bourne RR, Minassian DC, Dart JK, Rosen P, Kaushal $S$, Wingate $N$. Effect of cataract surgery on the corneal endothelium: modern phacoemulsification compared with extracapsular cataract surgery. Ophthalmology. 2004;111:679-85.

4. Joyce NC. Proliferative capacity of the corneal endothelium. Prog Retin Eye Res. 2003;22:359-89.

5. Fuchs E. Dystrophia epithelialis corneae. Graefes Arch Clin Exp Ophthalmol. 1910;76:478-508.
6. Krachmer JH, Purcell JJ Jr, Young CW, Bucher KD. Corneal endothelial dystrophy: a study of 64 families. Arch Ophthalmol. 1978;96:2036-9.

7. Adamis AP, Filatov V, Tripathi BJ, Tripathi RC. Fuchs' endothelial dystrophy of the cornea. Surv Ophthalmol. 1993;38:149-68.

8. Borboli S, Colby K. Mechanisms of disease: Fuchs' endothelial dystrophy. Ophthalmol Clin North Am. 2002;15:17-25.

9. Biswas S, Munier FL, Yardley J, et al. Missene mutations in COL8A2, the gene encoding the alpha2 chain of type VIII collagen, cause two forms of corneal endothelial dystrophy. Hum Mol Genet. 2001;10:2415-23.

10. Cross HE, Maumenee AE, Cantolino SJ. Inheritance of Fuchs' endothelial dystrophy. Arch Ophthalmol. 1971;85:268-72.

11. Maurice DM. The cornea and sclera. In: Davson $\mathrm{H}$, editor. The eye. New York: Academic Press; 1984.

12. Seitzman GD, Gottsch JD, Stark WJ. Cataract surgery in patients with Fuchs' corneal dystrophy: expanding recommendations for cataract surgery without simultaneous keratoplasty. Ophthalmology. 2005;112:441-6.

13. American Academy of Ophthalmology. Corneal endothelial photography. Ophthalmology. 1991;98:1464-8.

14. Mamalis N, Edelhauser HF, Dawson DG, et al. Toxic anterior segment syndrome. J Cataract Refract Surg. 2006;32:324-33.

15. Jehan FS, Mamalis N, Spencer TS, Fry LL, Kerstine RS, Olson RJ. Postoperative sterile endophthalmitis (TASS) associated with the memory lens. J Cataract Refract Surg. 2000;26:1773-7.

16. Parihk $\mathrm{CH}$, Edelhauser HF. Ocular surgical pharmacology: corneal endothelial safety and toxicity. Curr Opin Ophthalmol. 2003;14:178-85.

17. Moshirfar M, Whitehead G, Beutler BC, Mamalis N. Toxic anterior segment syndrome after Verisyse irissupported phakic intraocular lens implantation. J Cataract Refract Surg. 2006;32:1233-7.

18. Laibson PR. Part 1: introduction to corneal function and surgery, history of corneal surgery. In: Brightbill FS, McDonnell PJ, et al., editors. Corneal surgery technique and tissue. 4th ed. St. Louis: Mosby Elsevier; 2009. p. 1-7.

19. Reisinger F. Die keratoplastikeinversuchzurerweiterung der angenheilkunst. Bayer Ann. 1824;1:207-15. 
20. Bigger S. Inquiring into the possibility of transplanting the cornea, with the view of relieving blindness (hitherto deemed incurable) caused by several diseases of that structure. Dublin J Med Sci. 1837;11:408-17.

21. Kissam RS. Ceratoplastie in man. NY J Med. $1844 ; 2: 281-2$.

22. Power H. Zur transplantations rage der cornea klinischemout. Fur Augenheilkunde. 1878;16:35-9.

23. Zirm E. Eineerfolgreichetotalekeratoplastic. Graefes Arch Clin Exp Ophthalmol. 1906;64:580-93.

24. Magitot A. Transplantation of the human cornea previously preserved in an antiseptic fluid. JAMA. 1912;59:18-21.

25. Elschnig A, Vorisek EA. Keratoplasty. Arch Ophthalmol. 1930;4:165-73.

26. Gradle HS. The present status of keratoplasty. Am J Ophthalmol. 1921;4:895-9.

27. Thomas JWT. Transplantation of the cornea: a preliminary report on a series of experiments on rabbits, together with a demonstration of four rabbits with clear corneal grafts. Trans Ophthalmol Soc UK. 1930;50:127-41.

28. Filatov VP. Transplantation of the cornea. Arch Ophthalmol. 1935;13:321-47.

29. Castroviejo R. Atlas of keratectomy and keratoplasty. WB Saunders; 1966.

30. Castroviejo R. Keratoplasty. A historical and experimental study, including a new method. Am J Ophthalmol. 1932;15:825-38.

31. Castroviejo R. Keratoplasty. Comments on techniques of corneal transplantation. Source and preservation of donor's material. Report of new instruments. Am J Ophthalmol. 1941;24:139-55.

32. Paton RT. Symposium: Corneal transplantation. I. Selection of cases. Trans Am Acad Ophthalmol Otolaryngol. 1947-48; 52:312-16.

33. McLean JM. Symposium: Corneal transplantation. II. Technic. Trans Am Acad Ophthalmol Otolaryngol. 1947-48;52:317-21.

34. Castroviejo R. Keratoplasty. Symposium: Corneal transplantation. III. Complications. Trans Am Acad Ophthalmol Otolaryngol. 1947-48;52:322-30.

35. Maumenee AE, Kornbleuth W. Symposium: Corneal transplantation. IV. Physiopathology. Trans Am Acad Ophthalmol Otolaryngol. 1947-48;52:331-40.
36. Stocker FW. Successful corneal graft in a case of endothelial and epithelial dystrophy. Am J Ophthalmol. 1952;35:349-64.

37. Bourne WM. Examination and photography of donor corneal endothelium. Arch Ophthalmol. 1976;94:1799-800.

38. Khodadoust AA, Silverstein AM. The survival and rejection of epithelium in experimental corneal grafts. Invest Ophthalmol. 1969;8:169-79.

39. Owens WC. Symposium: Corneal transplantation. V. Results. Trans Am Acad Ophthalmol Otolaryngol. 1947-48;52:341-6.

40. Laibson PR. Max Fine's contribution to keratoplasty. Refract Corneal Surg. 1991;7:105-9.

41. Barraquer JI Jr. Technique of penetrating keratoplasty. Am J Ophthalmol. 1950;33:6-17.

42. Troutman RC (1974) Microsurgery of the anterior segment of the eye. Vol 1. Introduction and basic techniques. St Louis: CV Mosby Co.; 1974: 118-9.

43. The statistical report of EBBA Eye Bank association of America. Available from: http://www. restoresight.org/wp-content/uploads/2013/04/ 2012_Statistical_Report_FINAL-reduced-size-4-10. pdf. Last accessed: November 15, 2013.

44. McCarey BE, Kaufman HE. Improved corneal storage. Invest Ophthalmol. 1974;13:165.

45. Patel SV, Hodge DO, Bourne W. Corneal endothelium and postoperative outcomes 15 years after penetrating keratoplasty. Am J Ophthalmol. 2005;139:311-9.

46. Laibson PR, Rapuano CJ. 100-year review of cornea. Ophthalmology. 1996;103:517-28.

47. Tillett CW. Posterior lamellar keratoplasty. Am J Ophthalmol. 1956;41:530-3.

48. Barraquer JI. Lamellar keratoplasty. (Special techniques). Ann Ophthalmol. 1972;4:437-69.

49. Melles GR, Eggink FA, Lander F, et al. A surgical technique for posterior lamellar keratoplasty. Cornea. 1998;17:618-26.

50. Melles GR, Lander F, van Dooren BT, et al. Preliminary clinical results of posterior lamellar keratoplasty through a sclerocorneal pocket incision. Ophthalmology. 2000;107:1850-6 (discussion 1857).

51. Arthur W Giebel. DMEK: Where less is more. International ophthalmology clinics, vol. 53, no. 
1;2013, Philadelphia: Lippincott Williams and Wilkins.

52. Melles GRJ, Wijdh RHJ, Nieuwendaal CP. A technique to excise the Descemet membrane from a recipient cornea (descemetorhexis). Cornea. 2004;23:286-8.

53. Gorovoy MS. Descemet-stripping automated endothelial keratoplasty. Cornea. 2006;25:886-9.

54. Chen ES, Shamie N, Terry MA, et al. Endothelial keratoplasty: improvement of vision after healthy donor tissue exchange. Cornea. 2008;27:279-82.

55. Koenig SB, Covert DJ, Dupps WJ Jr, Meisler DM. Visual acuity, refractive error, and endothelial cell density six months after descemet stripping and automated endothelial keratoplasty (DSAEK). Cornea. 2007;26:670-4.

56. Price MO, Gorovoy M, Benetz BA, et al. Descemet's stripping automated endothelial keratoplasty outcomes compared with penetrating keratoplasty from the cornea donor study. Ophthalmology. 2010;117:438-44.

57. Bahar I, Sansanayudh W, Levinger E, Kaiserman I, Srinivasan S, Rootman D. Posterior lamellar keratoplasty-comparison of deep lamellar endothelial keratoplasty and Descemet stripping automated endothelial keratoplasty in the same patients: a patient's perspective. Br J Ophthalmol. 2009;93:186-90.

58. Melles GR, Ong TS, Ververs B, van der Wees J. Preliminary clinical results of Descemet membrane endothelial keratoplasty. Am J Ophthalmol. 2008;145:222-7.

59. Ham L, Dapena I, van Luijk C, van der Wees J, Melles GR. Descemet membrane endothelial keratoplasty (DMEK) for Fuchs endothelial dystrophy: review of the first 50 consecutive cases. Eye (Lond). 2009;23:1990-8.

60. Price MO, Giebel AW, Fairchild KM, Price FW Jr. Descemet's membrane endothelial keratoplasty: prospective multicenter study of visual and refractive outcomes and endothelial survival. Ophthalmology. 2009;116:2361-8.

61. Ham L, van Luijk C, Dapena I, et al. Endothelial cell density after descemet membrane endothelial keratoplasty: 1- to 2-year follow-up. Am J Ophthalmol. 2009;148:521-7.

62. Mearza AA, Qureshi MA, Rostron CK. Experience and 12-month results of Descemet-stripping endothelial keratoplasty (DSEK) with a smallincision technique. Cornea. 2007;26:279-83.
63. Guerra FP, Arundhati A, Price MO, Price FW. Endothelial keratoplasty: fellow eyes comparison of Descemet stripping automated endothelial keratoplasty and Descemet membrane endothelial keratoplasty. Cornea. 2011;30:1382-6.

64. Parker J, Dirisamer M, Naveiras M, Ham L, van der Wees J, Melles GR. Endothelial cell density after Descemet membrane endothelial keratoplasty: 1- to 4-year follow-up. Am J Ophthalmol. 2011;151:1107.

65. Price MO, Price FW Jr. Endothelial cell loss after Descemet stripping with endothelial keratoplasty influencing factors and 2-year trend. Ophthalmology. 2008;115:857-65.

66. Balachandran C, Ham L, Verschoor CA, Ong TS, van der Wees J, Melles GR. Spontaneous corneal clearance despite graft detachment in descemet membrane endothelial keratoplasty. Am J Ophthalmol. 2009;148:227-34.

67. Giebel AW. SCUBA technique for DMEK donor preparation. (2008). Available at http://www. youtube.com/watch? $\mathrm{v}=\mathrm{vpT}$ ToO8PFsvI\&feature= youtube_gdata_player. Accessed on: November 5, 2012.

68. Price FW, Price MO. DSEK: What you need to know about endothelial keratoplasty. Thorofare: Slack Inc.;2009, p. 170. il.

69. Giebel AW. Barosurgery, the surgical use of air, as a technique to promote adhesion between corneal layers in lamellar keratoplasty. Tech Ophthalmol. 2008;6:35-40.

70. Studeny P, Farkas A, Vokrojova M, et al. Descemet membrane endothelial keratoplasty with a stromal rim (DMEK-S). Br J Ophthalmol. 2010;94:909-14.

71. Pereira CDR, Guerra FP, Price FW Jr, et al. Descemet's membrane automated endothelial keratoplasty (DMAEK): visual outcomes and visual quality. Br J Ophthalmol. 2011;95:951-4.

72. McCauley MB, Price FW Jr, Price MO. Descemet membrane automated endothelial keratoplasty: hybrid technique combining DSAEK stability with DMEK visual results. J Cataract Refract Surg. 2009;35:1659-64.

73. Busin M, Patel AK, Scorcia V, et al. Stromal support for Descemet's membrane endothelial keratoplasty. Ophthalmology. 2010;117:2273-7.

74. Yoeruek E, Bayyoud T, Hofmann $\mathrm{J}$, et al. Comparison of pneumatic dissection and forceps dissection in Descemet membrane endothelial keratoplasty: histological and ultrastructural findings. Cornea. 2012;31:920-5. 
75. Venzano D, Pagani P, Randazzo N, et al. Descemet membrane air-bubble separation in donor corneas. J Cataract Refract Surg. 2010;36:2022-7.

76. Groeneveld-van Beek EA, Lie JT, van der Wees J, Bruinsma M, Melles GR. Standardized 'no-touch' donor tissue preparation for DALK and DMEK: harvesting undamaged anterior and posterior transplants from the same donor cornea. Acta Ophthalmol. 2013;91:145-50.

77. McKee HD, Irion LC, Carley FM, et al. Donor preparation using pneumatic dissection in endothelial keratoplasty: DMEK or DSEK? Cornea. 2012;31:798-800.
78. McKee HD, Irion LC, Carley FM, et al. Dissection planes in endothelial keratoplasty. Cornea. 2013;32:e136-7.

79. Güell JL, Morral M, Gris O, Elies D, Manero F. Bimanual technique for insertion and positioning of endothelium-Descemet. membrane graft in Descemet membrane endothelial keratoplasty. Cornea. 2013; 32:1521-6 (in press).

80. Hirata-Tominaga K, Nakamura T, Okumura N, et al. Corneal endothelial cell fate is maintained by LGR5 via the regulation of hedgehog and Wnt pathway. Stem Cells. 2013;31:1306-407. 